\title{
Relative size of gills of Cloeodes jaragua Salles \& Lugo-Ortiz, 2003 (Ephemeroptera, Baetidae) on pool and riffle areas of streams at the Atlantic Rainforest
}

\author{
Inês Corrêa Gonçalves ${ }^{1,5}$, Bruno Cid ${ }^{2}$, Amanda Frederico Mortati', \\ Letícia Barbosa Quesado ${ }^{4}$ \& Jorge Luiz Nessimian ${ }^{1}$ \\ ${ }^{1}$ Laboratório de Entomologia, Departamento de Zoologia, Instituto de Biologia, \\ Universidade Federal do Rio de Janeiro - UFRJ, Bloco A, sala 107, Ilha do Fundão, \\ CP 68044, CEP 21941-971, Rio de Janeiro, RJ, Brazil \\ ${ }^{2}$ Laboratório de Ecologia e Conservação de Populações, Departamento de Ecologia, \\ Instituto de Biologia, Universidade Federal do Rio de Janeiro - UFRJ, Bloco A, sala A027, \\ Ilha do Fundão, CP 68020, CEP 21941-971, Ilha do Fundão, Rio de Janeiro, RJ, Brazil \\ ${ }^{3}$ Departamento de Ciências Biológicas, Universidade do Estado de Mato Grosso - UNEMAT, \\ Campus de Alta Floresta, Rod. MT 208, Km 147, s/n, Bairro Jardim Tropical, \\ CEP 78580-000, Alta Floresta, MT, Brazil \\ ${ }^{4}$ Laboratório de Limnologia, Universidade Federal do Rio de Janeiro - UFRJ, \\ Av. Brigadeiro Trompowski, s/n, Prédio CCS, Bloco A, sub-solo, sala A0-008, \\ Ilha do Fundão, CP 68020, CEP 21941-971, Rio de Janeiro, RJ, Brazil \\ ${ }^{5}$ Corresponding author: Inês Corrêa Gonçalves, e-mail: inescg.bio@gmail.com
}

GONÇALVES, I.C., CID, B., MORTATI, A.F., QUESADO, L.B. \& NESSIMIAN, J.L. Relative size of gills of Cloeodes jaragua Salles \& Lugo-Ortiz, 2003 (Ephemeroptera, Baetidae) on pool and riffle areas of streams at the Atlantic Rainforest. Biota Neotrop. 11(2): http://www.biotaneotropica.org.br/v11n2/en/ abstract?article+bn03911022011.

\begin{abstract}
Physical environment of streams present many challenging factors to the organisms living under its influence. Water speed, one of the most important factors affecting such environments, has local influence on substrata, temperature, and oxygen levels. It acts determining species distributions and morphological and behavioral adaptations of organisms. The aim of this study was to assess the relative size of gills of Cloeodes jaragua on two mesohabitats: lentic environment (river dam) and lotic environment (fast flowing area of a stream) in Parque Nacional da Serra dos Órgãos (RJ, Brazil). Twenty individuals were collected on each environment and width of the head and gills were taken. Lentic environment showed nymphs with broader and more constant measurements than the lotic environment. The former, despite being composed of nymphs on different stages of development, presented individuals with narrower gills. Both, head width and environment type explained gills size, showing that streams habitat conditions are important in shaping the morphology of these animals.
\end{abstract}

Keywords: Ephemeroptera, aquatic insects, dam, stream, gills relative size, water speed.

GONÇALVES, I.C., CID, B., MORTATI, A.F., QUESADO, L.B. \& NESSIMIAN, J.L. Tamanho relativo das brânquias de Cloeodes jaragua Salles \& Lugo-Ortiz, 2003 (Ephemeroptera, Baetidae) em áreas de corredeiras e remansos em córregos na Mata Atlântica. Biota Neotrop. 11(2): http://www.biotaneotropica. org.br/v11n2/pt/abstract?article+bn03911022011.

Resumo: O ambiente físico dos rios apresenta diversos desafios para os organismos que vivem sob sua influência. A velocidade da água, um dos fatores mais importantes a atuar nesses ambientes, tem influência local no substrato, temperatura e oxigenação da água. A força da correnteza age determinando a distribuição das espécies e as adaptações morfológicas e comportamentais dos organismos. O objetivo desse estudo foi abordar o tamanho relativo das brânquias de Cloeodes jaragua em dois meso-habitats: um ambiente lêntico (represa) e um ambiente lótico (áreas de correnteza) no Parque Nacional da Serra dos Órgãos - RJ. Um total de 20 indivíduos foi coletado em cada tipo de ambiente e as larguras da cabeça e brânquias foram medidas. O ambiente lêntico apresentou ninfas com medidas mais largas e mais constantes que o ambiente lótico. Este último, apesar de ser composto por ninfas em diferentes estágios de desenvolvimento, apresentou indivíduos com menores larguras de brânquias. Ambos, largura da cabeça e tipo de ambiente, explicaram o tamanho das brânquias, mostrando as condições dos habitats dos rios como importantes modeladores da morfologia desses animais.

Palavras-chave: Ephemeroptera, insetos aquáticos, represa, rio, tamanho relativo das brânquias, velocidade da água. 


\section{Introduction}

Baetid nymphs inhabit a variety of lotic and lentic habitats, occupying sandy and rocky substrates as well as aquatic plants. They are found in the full range of lotic habitats and while some nymphs are not tolerant to poorly oxygenated water, others are able to live where oxygen levels are quite low (Domínguez et al. 2006). For instance, nymphs of Americabaetis alphus Lugo-Ortiz \& McCafferty, 1996, A. longetron Lugo-Ortiz \& McCafferty, 1996, Cloeodes irvingi Waltz \& McCafferty, 1987, Paracloeodes eurybranchus Lugo-Ortiz \& McCafferty, 1996, and Zelusia principalis Lugo-Ortiz \& McCafferty, 1998 have been found on both, pool and riffle areas of streams (Salles et al. 2003). Another baetid genus, Callibaetis, typically inhabits lentic habitats although can also be found on pool areas of lotic systems (Salles et al. 2003).

The genus Cloeodes is a widespread Neotropical group whose nymphs have been collected in a wide diversity of habitats (Waltz \& McCafferty 1987, Domínguez et al. 2006). Nymphs can be found in well-oxygenated rivers as well as in those that are poorly-oxygenated (Domínguez et al. 2006), occupying either riffle or pool areas of streams, backwaters or temporary pools (e.g. Nolte et al. 1996, Salles \& Lugo-Ortiz 2003, Salles et al. 2003, 2004).

Water speed, the major factor that differs lotic and lentic environments, is considered one of the main factors affecting composition and abundance of streams' communities (Allan 2001). Water current has direct influence on temperature, oxygen levels, and local substrata types. It exerts friction upon individuals and increases habitat heterogeneity thus influencing morphological adaptations of species (Cummins \& Lauf 1969, Allan 2001).

When there is spatial heterogeneity within the range of a population, it is unlikely that a single phenotype will confer high fitness in all situations (Via et al. 1995). Considering the strong influence of the water speed in several features of the stream environment (Allan 2001, Gordon \& McMahon 2004), particularly on oxygen levels, it is likely that the pressure upon some morphological traits will be distinct in places where water speed is different. Aquatic insects have shown phenotypic plasticity through changes in morphological development in response to different water flow regimes (Lancaster \& Belyea 1997, Zhang \& Malmqvist 1997, Franken et al. 2008) and oxygen levels (e.g. Loudon 1989, Harrison \& Lighton 1998), such plasticity can help them decrease or even cancel oxygen restriction (Okajima 2008). Current speed affects directly water oxygen levels and concentration of dissolved oxygen on rapid flowing water is usually near to air saturation (Baümer et al. 2000, Allan 2001). For this reason, individuals living on poorly oxygenated conditions such as those of lentic habitat would need gill lamellae to have a larger area in order to attain enough oxygen to its metabolic demand than it would be necessary for those individuals living on highly oxygenated water. It is expected that broader gills provide a greater respiratory absorption area and thus aid specimens to acquire its necessary levels of oxygen.

According to the foregoing, in this study we analyze whether differences on gill width take place on nymphs of Cloeodes jaragua Salles \& Lugo-Ortiz, 2003 when inhabiting two different environments with distinct water flow regimens: running water environment represented by a riffle area of a stream bed and still water environment represented by a pool area of a stream dam. Therefore, we hypothesize that habitat can influence gill width of the small minnow mayfly Cloeodes jaragua becoming narrower at the stream bed than at the stream dam.

\section{Material and Methods}

The study was carried out in Parque Nacional da Serra dos Órgãos, at the municipality of Teresópolis, Rio de Janeiro, Brazil. It occupies over 10,000 ha $\left(22^{\circ} 24^{\prime}-22^{\circ} 32^{\prime} \mathrm{S}\right.$ and $\left.42^{\circ} 69^{\prime}-43^{\circ} 06^{\prime} \mathrm{W}\right)$ and includes the higher parts of Serra dos Órgãos, with altitudes ranging from 300 to 2,263 m (RadamBrasil 1983). Sampling sites altitude were about $1,000 \mathrm{~m}$.

Two third order tributaries, about $200 \mathrm{~m}$ distant from each other, were studied: the Beija-Flor river dam (lentic environment) and the fast flowing waters of the Paquequer River (lotic environment). The dam is an artificial dike of rocky walls with sandy bottom and wide litter pools on standing water. The fast flowing water system has a course composed by boulders, pebbles, rocks, and sand with a fast water current produced by its marked slope.

A surber collector $(0,2 \mathrm{~mm}$ mesh) was used to gather 20 individuals of $C$. jaragua in each sampling site. Specimens were preserved in $80 \%$ ethanol and measured on laboratory. Four body measures were taken: body and third gill lengths, and head and third gill maximum widths. Body measurements were made directly in stereomicroscope and gills were removed, photographed, and measured in Photoshop ${ }^{\circledR}$ CS3 software.

Current speed was estimated by the head rod method (Waterwatch Australia Steering Committee 2002): depth was accessed three times in each sampling point using both, thin and flat, sides of the ruler facing the flow. The average difference between these two measurements (h) was used to determinate current speed by the formula: $\mathrm{V}(\mathrm{m} / \mathrm{s})=\sqrt{2}(2 \times 9.81 \times \mathrm{h})$, where 9.81 is the gravitational constant. Oxygen was not measured, but its variation was assumed for the current speed variation, since they are closely related and co-vary in this systems.

In order to remove head width effect on gill width, a rate between gill and head widths was made. In order to investigate relations between gill size and sampling site (therefore, its relation with water speed) a $t$-test using the rate values between sites was performed. Self-correlated variables based on Pearson's correlation tests were not used. Statistical analysis were performed using SYSTAT ${ }^{\circledR} 11$ software (SYSTAT 2004).

\section{Results}

Average water speed was higher at the lotic environment $(\sim 4 \mathrm{~m} / \mathrm{s})$ than at the lentic $(\sim 0 \mathrm{~m} / \mathrm{s})$. Body and head measurements were less variable and had higher values in the lentic habitat than in the lotic habitat (Figure 1). A positive correlation was found between body length and head width $(\mathrm{r}=0.86)$, and between gill length and width $(r=0.93)$. Therefore, only gill and head widths were used in the subsequent analysis. These two measurements seem to be more relevant once head width is a stable measurement in insects, while body length varies according to specimens' preservation process, once the animal can control body contractions. As a result, head width is a more accurate reflex of the animal stage of development, thus more reliable. Moreover, gill width demonstrated to be more appropriated than gill length because it can be affected by the current strength and oxygen levels.

Gill/head widths ratio was higher at the lentic environment $(0.3 \pm 0.05 ; \mathrm{n}=20)$ rather than at the lotic environment $(0.2 \pm 0.04)$ (Figure 2) $(\mathrm{t}=4.63$; D.F $=38 ; \mathrm{p}<0.001)$ showing that gills at the lentic habitat are broader than at the lotic habitat in relation to size of the heads (Figure 3). 

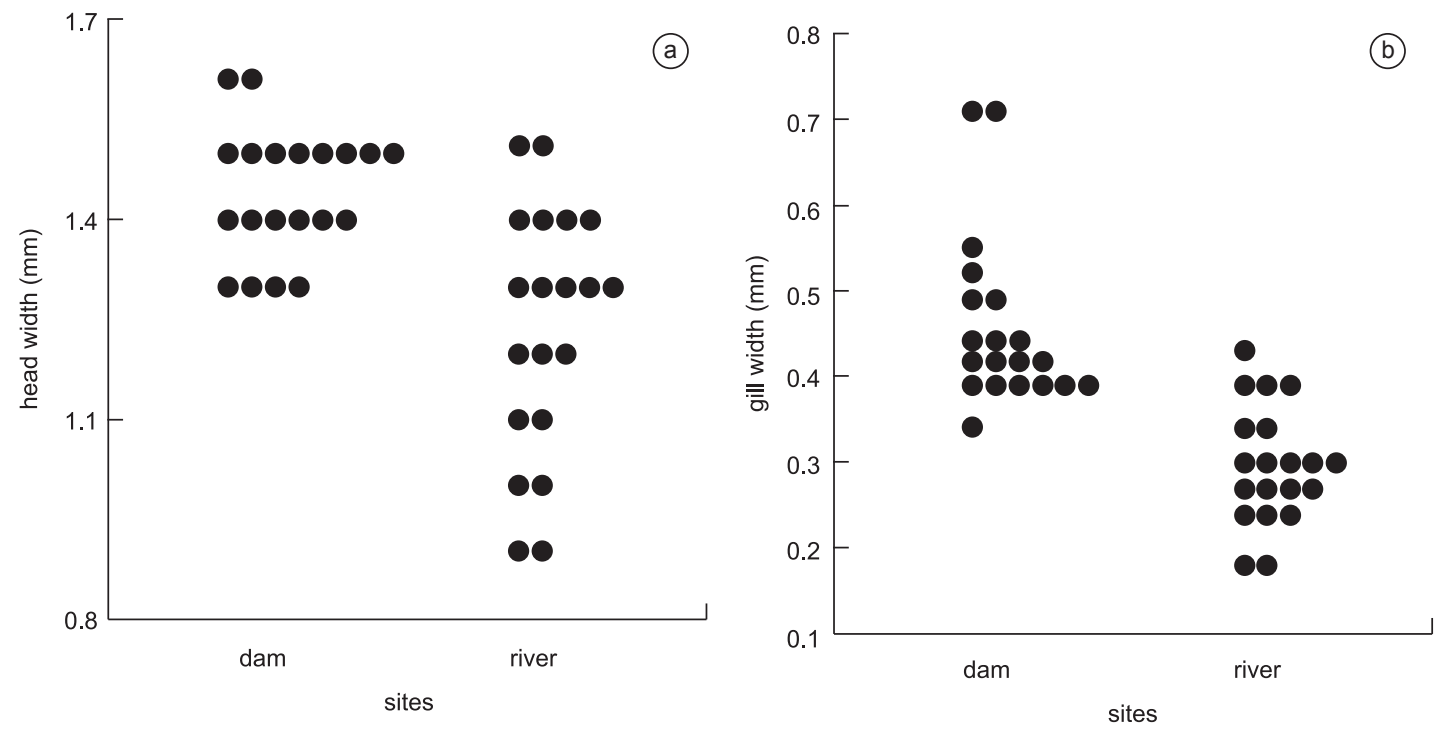

Figure 1. Body measurements of Cloeodes jaragua $(\mathrm{n}=40)$ in the dam and fast flowing water in the Parque Nacional da Serra dos Orgãos. a) Head widths $(\mathrm{n}=20)$; and $\mathrm{b})$ Gill widths $(\mathrm{n}=20)$. Each dot is an individual of $C$. jaragua.

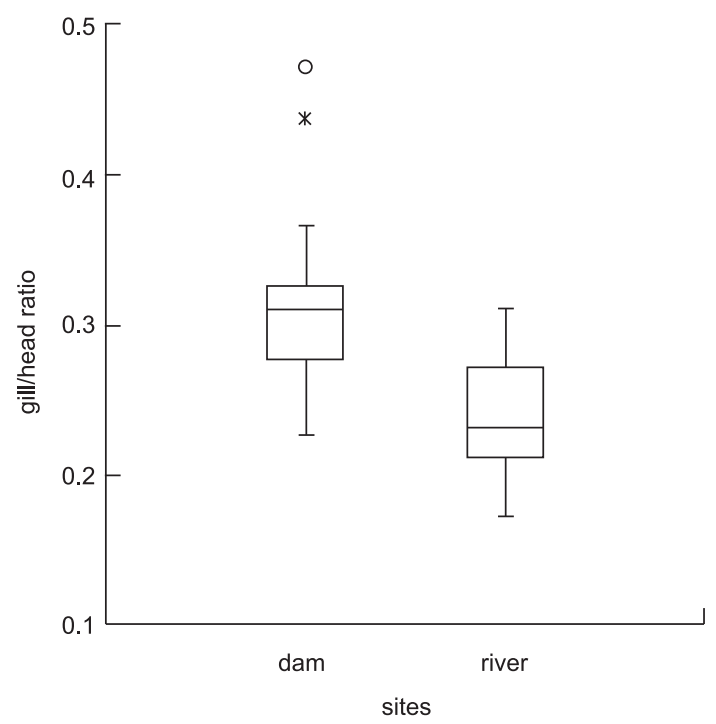

Figure 2. Gill/head widths ratio of Cloeodes jaragua $(\mathrm{n}=40)$ in the dam $(\mathrm{n}=20)$ and fast flowing water $(\mathrm{n}=20)$ in Parque Nacional da Serra dos Órgãos.

\section{Discussion}

Mayflies have shown the ability to alter their development in response to other variable environmental pressures (Dahl \& Peckarsky 2003). These variations are possible in a population that shows phenotypic plasticity, in which individuals are able to explore a wider range of resources. This can benefit the population as a whole by exploring a wider range of food items more effectively (Pianka 2000).

Differences between the two sites may be related to the physical characteristics of both environments. The lower number of broader heads (and consequently of larger nymphs) observed on the lotic environment may be allied to the fact that such nymphs are probably

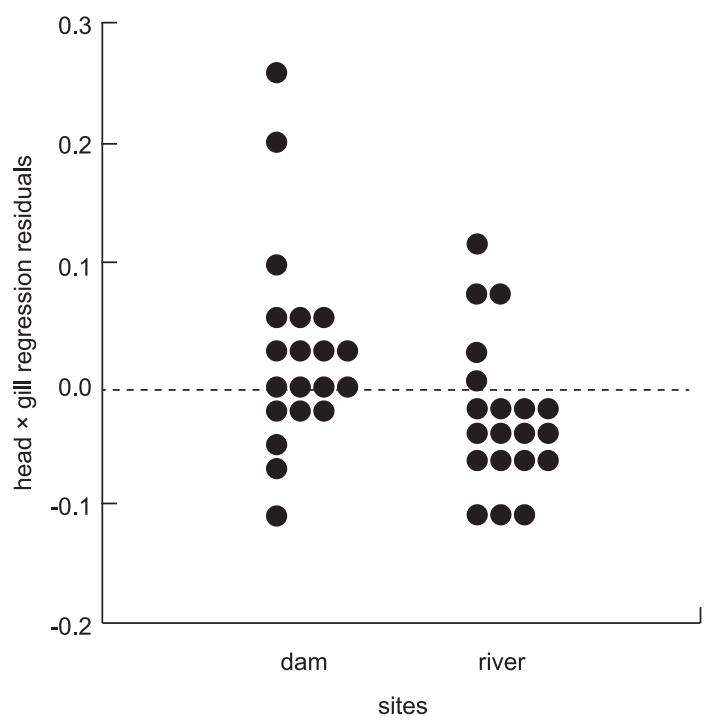

Figure 3. Head $\times$ gills regression residuals of Cloeodes jaragua in the dam $(\mathrm{n}=20)$ and fast flowing water $(\mathrm{n}=20)$ in Parque Nacional da Serra dos Órgãos. Each dot is an individual $C$. jaragua. The dashed line indicates the point where gills width had the expected value in relation to head width (the dots above the dashed line belong to individuals with larger gills than the expected for head width).

occupying areas with slower current. Nymphs of Cloeodes lack morphological characteristics to resist fast water flows such as the strong legs in Camelobaetidius or the denticles of the tarsal claws found in Baetodes (Buss \& Salles 2007), thus being unable to remain under fast water flow conditions.

According to gill/head ratio, gills were relatively larger at the lentic than at the lotic environment. That means that specimens of Cloeodes jaragua of similar sizes tended to have broader gills at the dam whereas gills tended to be narrower in individuals found at the fast flowing water area. There are two possible factors affecting this result: oxygen levels and water physical abrasion. In the latter, stream current would be an intermediate disturbance (Connell 1978) 
contributing to the relaxation of intraspecific competition. Specimens with broader gills can be affected by friction in faster water flows, becoming more susceptible to drift and, as discussed previously, Cloeodes species do not possess morphological adaptations to resist fast current flows. This can also be noticed by the reduced number of larger heads in fast flowing water. Smaller individuals are less susceptible to drift and bigger nymphs can compensate their sizes with narrower gills, once oxygen levels are not a limitation.

Our results point to an ability of nymphs of Cloeodes jaragua to respond to different environment characteristics (lentic and lotic), thus being able to support a considerable range of water speeds. The rapid flow, besides increasing the environmental heterogeneity and be a relevant abrasive strength, provides the continuous renewal of water in contact with the respiratory structures in lotic environments. Species that occur in these environments are highly dependent on this ready availability of oxygen (Hynes 1970). Nevertheless, insects that occupy lentic sites can compensate for lack of oxygen renewal by making use of variations in morphology. Here, $C$. jaragua showed gills with greater surface area for gas exchange in environments with lower water flow. Since studies on this issue are rare on aquatic insects, it is possible that this kind of answer is not restricted to C. jaragua and may be presented by other groups.

\section{Acknowledgements}

We are thankful to ICMBIO and Parque Nacional da Serra dos Órgãos for collecting permits and facilities. To CNPq, Programa de Pós-graduação em Zoologia - UFRJ and Programa de Pós-graduação em Ecologia - UFRJ for supporting this research. We are also thankful to members of Laboratório de Entomologia, - UFRJ for help on field trip and to the anonymous reviewers and editor Dr. Fábio de Oliveira Roque for important suggestions and corrections on the manuscript.

\section{References}

ALLAN, JD. 2001. Stream Ecology: Structure and Function of Running Waters. Chapman \& Hall.

BAÜMER, C., PIROW, R. \& PAUL, R.J. 2000. Respiratory Adaptations to Running-Water Microhabitats in Mayfly Larvae Epeorus sylvicola and Ecdyonurus torrentis, Ephemeroptera. Physiol. Biochem. Zool. 73(1):77-85. PMid:10685909. http://dx.doi.org/10.1086/316720

BUSS, D. \& SALLES, F.F. 2007. Using Baetid Species as Biological Indicators of Environmental Degradation in a Brazilian River Basin. Environ. Monit. Assess. 130:365-372. PMid:17106778. http://dx.doi.org/10.1007/ s10661-006-9403-6

CONNELL, J.H. 1978. Diversity in tropical rainforests and coral reefs. Science. 199:1302-10. PMid:17840770. http://dx.doi.org/10.1126/ science.199.4335.1302

CUMMINS, K.W. \& LAUFF, G.H. 1969. The influence of substrate particle size on the microdistribution of stream macrobenthos. Hydrobiologia. 34:145-81. http://dx.doi.org/10.1007/BF00141925

DAHL, J. \& PECKARSKY, B.L. 2003. Developmental responses to predation risk in morphologically defended mayflies. Oecologia. 137:188-194. PMid:12851808. http://dx.doi.org/10.1007/s00442-003-1326-0

DOMÍNGUEZ, E., MOLINERI, C., PESCADOR, M.L., HUBBARD, M.D. \& NIETO, C. 2006. Ephemeroptera of South America. In Aquatic Biodiversity in Latin America (ABLA) (J. Addis, J.R. Arias, G. RuedaDelgado \& K.M. Wantseb, edis.). Pensoft.
FRANKEN, R.J.M., GARDENIERS, J.J.P., BEIJER, J.A.J. \& PEETERS, E.T.H.M. 2008. Variation in stonefly (Nemoura cinerea Retzius) growth and development in reponse to hydraulic and substrate conditions. J. N. Am. Benthol. Soc. 27:176-185. http://dx.doi.org/10.1899/07-066.1

GORDON, N.D., McMAHON, T.A., FINLAYSON, B.L., GIPPEL, C.J. \& NATHAN, R.J. 2004. Stream hydrology: an introduction for ecologists. Wiley, West Sussex.

HARRISON, J.F. \& LIGHTON, J.R. 1998. Oxygen-sensitive flight metabolism in the dragonfly Erythemis simplicicollis. J. Exp. Biol. 201:1739-1744.

HYNES, H.B.N. 1970. The ecology of running waters. University of Toronto Press, Toronto.

LANCASTER, J. \& BELYEA, L.R. 1997. Nested hierarchies and scaledependence of mechanisms of flow refugium use. J. N. Am. Benthol. Soc. 16:221-238. http://dx.doi.org/10.2307/1468253

LOUDON, C. 1989. Tracheal hypertrophy in mealworms: design and plasticity in oxygen supply systems. J. Exp. Biol. 147:217-235.

NOLTE, U., TIETBÖHL, R.S. \& McCAFFERTY, W.P. 1996. A mayfly from tropical Brazil capable of tolerating short-term dehydration. J. N. Am. Benthol. Soc. 15(1):87-94. http://dx.doi.org/10.2307/1467434

OKAJIMA, R. 2008. The controlling factors limiting maximum body size of insects. Lethaia, 41(4):423-430. http://dx.doi.org/10.1111/j.15023931.2008.00094.x

PIANKA, E.R. 2000. Evolutionary Ecology. 6nd ed. Benjamin-Cummings, San Francisco.

RADAMBRASIL. 1983. Levantamento dos Recursos Naturais. Ministério das Minas e Energia, 32p.

SALLES, F.F., BATISTA, J.D. \& CABETTE, H.R.S. 2004. Baetidae (Insecta: Ephemeroptera) de Nova Xavantina, Mato Grosso, Brasil: Novos registros e descrição de uma nova espécie de Cloeodes Traver. Biota Neotrop. $4(2): 1-8$.

SALLES, F.F., FRANCISCHETTI, C.N., ROQUE, F.O., PEPINELLI, M. \& STRIXINO, S.T. 2003. Levantamento preliminar dos gêneros e espécies de Baetidae (Insecta: Ephemeroptera) do Estado de São Paulo, com ênfase em coletas realizadas em córregos florestados de baixa ordem. Biota Neotrop. 3:1-7.

SALLES, F.F. \& LUGO-ORTIZ, C.R. 2003. Nova espécie de Cloeodes Traver (Ephemeroptera: Baetidae) do Estado do Rio de Janeiro. Neotrop. Entomol. 32(3):449-452. http://dx.doi.org/10.1590/S1519566X2003000300011

SYSTAT. 2004. Systat Software, Version 11. Systat Software, Inc.

VIA, S., GOMULKIEWICZ, R., DE JONG, G., SCHEINER, S.M., SCHLICHTING, C.D. \& VAN TIENDEREN, P.H. 1995. Adaptive phenotypic plasticity: consensus and controversy. Trends Ecol. Evol. 10:212-217. http://dx.doi.org/10.1016/S0169-5347(00)89061-8

WALTZ, R.D. \& MCCAFFERTY, W.P. 1987. Revision of the genus Cloeodes Traver (Ephemeroptera: Baetidae) in Africa. Ann. Entomol. Soc. Am. 80(2):191-207.

WATERWATCH AUSTRALIA STEERING COMMITTEE. 2002. Module 4-Physical and Chemical parameters. In: Waterwatch Australia National Technical Manual. Environmental Australia, Canberra. waterwatch.org. au/libray/ (ultimo acesso em 23/10/2009).

ZHANG, Y.\& MALMQVIST, B. 1997. Phenotipic plasticity in a suspensionfeeding insect, Simulium lundstromi (Diptera: Simuliidade) in response to currenty velocity. Oikos. 78:503-510. http://dx.doi.org/10.2307/3545611 